\title{
Influence of morphology on the ventilation of polluted areas - a case study from
}

\author{
Rybnik Plateau, Poland
}

\author{
Jolanta Radosz
}

Department of Physical Geography, Faculty of Earth Sciences, University of Silesia, Będzińska Str. 60, 41-200 Sosnowiec, Poland E-mail address: jolantarsc@gmail.com

\begin{abstract}
In the present study an attempt was made to determine the degree of effective ventilation of the valleys in the area of the Rybnik Plateau, based on the example of the environs of Jastrzębie Zdrój, a city with high air pollution. For the analysis of the conditions of airing of valleys the areas with different physico-geographical characteristics, primarily in terms of density of the valley network, origin and morphology of the valleys, and type of surface deposits were selected. 49 cross-valley profiles were drawn for the selected valleys; on the basis of the profiles the following parameters were calculated: the distances between the edges of each valley, valley bottom width, and depth of the valleys. The degree of ventilation of each valley was calculated after the formulae of Kaps (1955) and Błażejczyk (1975). The lowest values of the index of effective ventilation were recorded almost in all main loessial valleys in the southern part of the area. This indicates their weak or even extremely weak degree of ventilation. The valleys in the remaining area, open predominantly to $\mathrm{N}$ and $\mathrm{E}$, are most commonly aired to a sufficient degree. This is determined by their morphology, especially smaller depth, smaller relative heights and higher mean wind speed. The example presented in this study shows that the index of effective ventilation, even if it is calculated for a relatively small area, reflects the characteristics of the local environment extremely well which is relevant from the perspective of the movement of contaminated air.
\end{abstract}

KEY WORDS: topoclimate, air circulation, valley wind, Silesian Upland

\section{Introduction}

Local physiographic conditions have a significant impact on the movement of air masses, as exemplified by types of wind such as breeze, föhn, bora and others. The impact of the relief of the area on the speed and direction of winds is extensively discussed in the world literature, on the basis of both direct field research and empirical models (SMITH, 1978; BRADLEY, 1980; BRITTER ET AL., 1981; TAYLOR \& LEE, 1984; EGGER, 1987; BAR \& ORGILl, 1989; WhITEMAN \& DORAN, 1993; DOYLE \& SHAPIRO, 1999; RAMPANELLI ET AL., 2004; PETERSEN ET AL., 2005; REUDER \& EGGER, 2006; NGO \& LETCHFORS, 2008; MiKITA \& KLIMÁNEK, 2010; ZARDI \& WHITEMAN, 2012). In the Polish geographical literature the question of the impact of topographical conditions on the wind speed is discussed with respect to mountainous areas, to which the discussion about the mountain-valley circulation refers (BŁAŻEJCZYK, 1975; KRAWCZYK \& BŁAŻEJCZYK, 1982; BĄKOWSKI, 2000; TREPIŃSKA \& KOWANETZ, 2000; BŁAŻEJCZYK \& KUCHCIK, 2003), and with respect to upland areas (e.g. KLEIN, 1967; HESS, 1969; RADOMSKI, 1977; KŁYSIK, 1985; BAC ET AL., 1993; RADOSZ, 2007a,b, 2008; BURZYŃSKA, 2009; PICHOWSKA, 2009; SŁOWIK, 2009; UKLEJA, 2009). It follows from this research that the wind speed depends on the wind direction in relation to the course of the valley, those winds that blow in wide valleys are stronger than in narrow valleys, and the obstacles and constrictions in the valleys significantly modify the direction of the wind and its speed. Along with the reduction in wind speed the intensity of turbulence decreases, therefore the conditions for the exchange of air masses and diffusion are worse in the valleys than in comparison with those of the plains. Due to the low temperatures that are characteristic of 
the bottom of the valleys at night and in winter, inversion layers are formed which may completely prevent the exchange of air masses. Weak turbulence in the valleys leads to the following consequences: poor air quality if the sources of emissions are located in the valley, occurrence of extreme temperatures, high air humidity and frequent occurrence of fog (FLEMMING, 1983). For these reasons, the airing of valleys is an essential issue from the point of view of the quality of life of people living in the valleys. Mountain and valley winds which are observed in the mountains change direction twice a day. This type of circulation has a favourable impact on the climate of the villages located in the high mountain valleys, such as health resorts, since it supports the flowing away of the residual contaminated air and inflow of fresh mountain air (RADOMSKI, 1977). The airing of valleys is weaker in the highlands, which in the case of the occurrence of emitters of air pollution causes environmental problems. In the present study an attempt was made to determine the degree of effective airing of the valleys in the area of the Rybnik Plateau, based on the example of the environs of Jastrzębie Zdrój, a city with high air pollution. This study is a follow-up to the studies on the topoclimatic conditions of the Rybnik Plateau (KAMIŃSKI \& RADOSZ, 1991; DEGÓRSKA ET AL., 1995; RADOSZ ET AL., 2004, RADOSZ, 2007c).

\section{Study area}

The study area is located in the south-western part of the Silesian Upland, which is referred to as the Rybnik Plateau in the regional breakdown (KONDRACKI, 1998). The analysed area covers less than $15 \mathrm{~km}^{2}$; it extends between the cities of Jastrzębie Zdrój and Żory. Nearly $3 / 4$ of the described area is dewatered by the River Szotkówka and its tributaries, and the remaining area is dewatered by the source sections of the Pszczynka river, Kłokocinka stream and their tributaries. The analysed area is located in the south-western part of the Upper Silesian Coal Basin with a mining tradition dating back to the late $18^{\text {th }}$ century. After the Second World War 7 new hard coal mines were constructed and an intensive development of the industry was started (Dulias, 2011). As a result, the environment was subjected to a strong anthropogenic impact on the environment numerous mining waste disposal sites and subsidence basins were created, the river waters were drastically polluted and the air quality deteriorated (JANKOWSKI, 1986). Due to the southwestern direction of the dominant wind in the region the pollutants from the Ostrava-Karviná
Coal Basin in the Czech Republic are also transported to the study area, which allows for an extensive lowering of the Moravian Gate. Between 1961 and 1990, an average of $19.2 \%$ of winds blew from the south-west direction, and at the same time the winds have the highest average speed of $3.2 \mathrm{~m} / \mathrm{s}$ (average for all directions is $2.2 \mathrm{~m} / \mathrm{s}$ ) (CHARAKTERYSTYKA KLIMATOLOGICZNA, 1992).

For the analysis of the conditions of airing the valleys the areas with different physicogeographical characteristics, primarily in terms of density of the valley network, origin and morphology of the valleys, and type of surface deposits were selected (MAPA GEOLOGICZNA, 1979). The western part of the test area is characterised by the occurrence of loessial formations, within the borders of which numerous erosion valleys resembling gullies were formed. A dense network of narrow and quite deep valleys divides a slightly rolling surface of the plateau into a number of gullies (DWUCET, 1981, 1986). The eastern part of the study area is characterised by a more monotonous relief, valleys are shallower and wider, and the cover of the surface deposits is composed of sandy and dusty-sandy sediments. The environmental characteristics listed above are reflected by the thermal and humidity conditions affecting the local climate. The valleys situated in the Szotkówka, Pszczynka and Kłokocinka catchment basins were selected for the analysis.

\section{Research methods}

The morphometric characteristics of the valleys were analysed on the basis of the topographic map at scale 1:10 000 (MAPA TOPOGRAFICZNA, 1993). 49 cross-valley profiles were drawn for the selected valleys; on the basis of the profiles the following parameters were calculated: the distances between the edges of valley $b$, valley bottom width $d$, and depth of the valleys $h$. Kaps' ventilation index $D$ was calculated according to the formula (KAPS, 1955):

$$
D=d / d+b \cdot d / h
$$

The method of calculation of the said index does not take into account the anemological conditions that are crucial to the dispersion of pollutants (BŁAŻEJCZYK, 1975). As suggested by the author the mean wind speeds from 8 directions for the cities of Jastrzębie Zdrój and Rybnik (ŚWIĘTOŃ, 1981) were compared and the index of effective ventilation - De was calculated.

$$
D e=D \cdot v
$$


where: $D e$ - is the index of effective ventilation, $D$ - is the Kaps' ventilation index, $v$ - is the ratio of the mean speed of the wind blowing from a certain direction to the minimum speed causing turbulence.

In the classification of wind speed ranges for the purposes of climate studies, it is assumed that a weak turbulence occurs even at very low wind $>0-2 \mathrm{~m} / \mathrm{s}$ (PARCZEWSKI, 1960). Thus, the value of $v$ is de facto a value representing the mean wind speed. The data provided in Table 1 indicate the incomparability of the aforementioned methods of assessment of the degree of ventilation of valleys (KAPS, 1955; BŁAŻEJCZYK, 1975).

Table 1. The degree of ventilation of valleys after Kaps (1955) and Błażejczyk (1975)

\begin{tabular}{|c|c|c|c|}
\hline Index of ventilation & $\begin{array}{c}\text { The degree of ventilation after Kaps } \\
(1955)\end{array}$ & Index of ventilation & $\begin{array}{c}\text { The degree of ventilation after } \\
\text { Błażejczyk (1975) }\end{array}$ \\
\hline less than 1 & very bad & less than 15.1 & extremely weak \\
\hline $3-6$ & insufficient & $15.1-30.0$ & very weak \\
\hline $7-10$ & moderate & $30.1-60.0$ & weak \\
\hline $11-14$ & not always sufficient & $60.1-90.0$ & sufficient \\
\hline more than 15 & sufficient & $90.1-120.0$ & strong strong \\
\hline & & $120.1-150.0$ & very strong \\
\hline
\end{tabular}

The value of effective ventilation $D e_{w}$ including the frequency of occurrence of winds from different directions was calculated according to the formula:

$$
D e_{w}=\sum(D e \cdot n) / \sum n
$$

where: $D e_{w}$ - is the weighted mean value of the index of effective ventilation, $D e-$ is the value of the index of effective ventilation, $n$ - the frequency of winds from a given direction in $\%$, where $\sum n=$ $100 \%$.

As a result of the research method applied in this manner a network of points located at the bottoms of the valleys together with the $D e_{w}$ values assigned to them was obtained; the spatial distribution of effective ventilation is shown with the use of the isarithmic method.

\section{Results}

The valley of the Szotkówka river in its headwaters is characterised by a narrow bottom with a width of 30-50 m, steep slopes and depth of 10-20 m(Fig. 1A). The $D$ index calculated for the cross-valley profile in the headwaters does not exceed the value of 18 , and when converted into effective ventilation $D e_{w}$ it equals 24.9 (Tab. 2 ), which indicates a very low degree of ventilation (Tab. 1). The values of ventilation are insignificantly higher for the middle section of the valley, at the point of its connection with numerous side valleys and where the width of the bottom is greater (Tab. 2, Fig. 1B). $D e_{w}$ index with a value of 31.6 indicates a weak degree of ventilation of the valley (Tab. 1). Approximated values of the index of ventilation were calculated for the lower section of the River Szotkówka (Tab. 2, Fig. 1C). It should be emphasised that the major course of the axis of the main valley is $\mathrm{N}-\mathrm{S}$.

It can be concluded from the results presented above that the morphology of the valley of the upper section of the River Szotkówka does not create the conditions for greater air flow. This statement applies to both wide and flat-bottomed sections of the valley, but also to its narrow and $v$-shaped fragments. Improper aerodynamic conditions result in poor heat exchange through turbulence, limited vertical transfer of water vapour, fog formation, and stagnation of cold air. Poor air exchange in the valley open towards the south may at the same time be conducive to the stagnation of pollutants transported from the Czech Republic through the Moravian Gate.

Particularly unfavourable aerosanitary conditions may occur in the valley of the left tributary of the River Szotkówka, in the lower section of which a large mining waste disposal site was established. The lowest values of the ventilation indices were calculated for this valley. For the cross profiles in the immediate vicinity of the disposal site the value of the ventilation index $D$ ranges from 10.3 to between 13-16, and the value of the index of effective ventilation $D e_{w}$ corresponds to extremely weak ventilation. Based on the previous studies it was found that the impact of the spoil tip reaches up to $2-2.5 \mathrm{~km}$ from its slopes, and the described valley is sited in the zone of wind speed reduced by tens of percent (DEGóRSKA ET AL., 1995). Estimates show that the sedimentation of solid pollutants is increased from 2 to $4 \%$. In 2000 , in 
the nearby city of Jastrzębie Zdrój the average dust-deposits amounted to $61 \mathrm{~g} / \mathrm{m}^{2}$, thus 1.22 $2.44 \mathrm{~g} / \mathrm{m}^{2}$ more solid pollutants reached the valley under consideration, located in the way of the prevailing winds from the side of the said city, than in the neighbouring areas. Currently, these values are small, but in 1987 from 3.7 to $7.5 \mathrm{~g}$ more solid substances sedimented per each square metre (MŁYNARCZYK, 2002). Definitely better aerosanitary conditions occur in the valley of the left tributary of the River Pszczynka (Fig. 1D), situated further to the east of the disposal site and open towards the east, which in combination with the prevailing westerly winds results in sufficient ventilation of the valley. The index of effective ventilation $D e_{w}$ is 77.4 (Tab. 2).

Table 2. Index of ventilation $D$ and weighted mean value of the index of effective ventilation $D e_{w}$ for selected transverse profiles through the Szotkówka and Pszczynka valleys

\begin{tabular}{|c|c|c|c|}
\hline Profile number & Directions & Index of ventilation $D$ & $\begin{array}{c}\text { Index of effective ventilation } \mathrm{De}_{\mathrm{w}} \\
\text { (weighted mean value) }\end{array}$ \\
\hline I & W - E & 17.4 & 24.9 \\
\hline II & SW - NE & 22.0 & 31.6 \\
\hline III & W - E & 23.9 & 34.2 \\
\hline IV & SW - NE & 54.0 & 77.4 \\
\hline
\end{tabular}
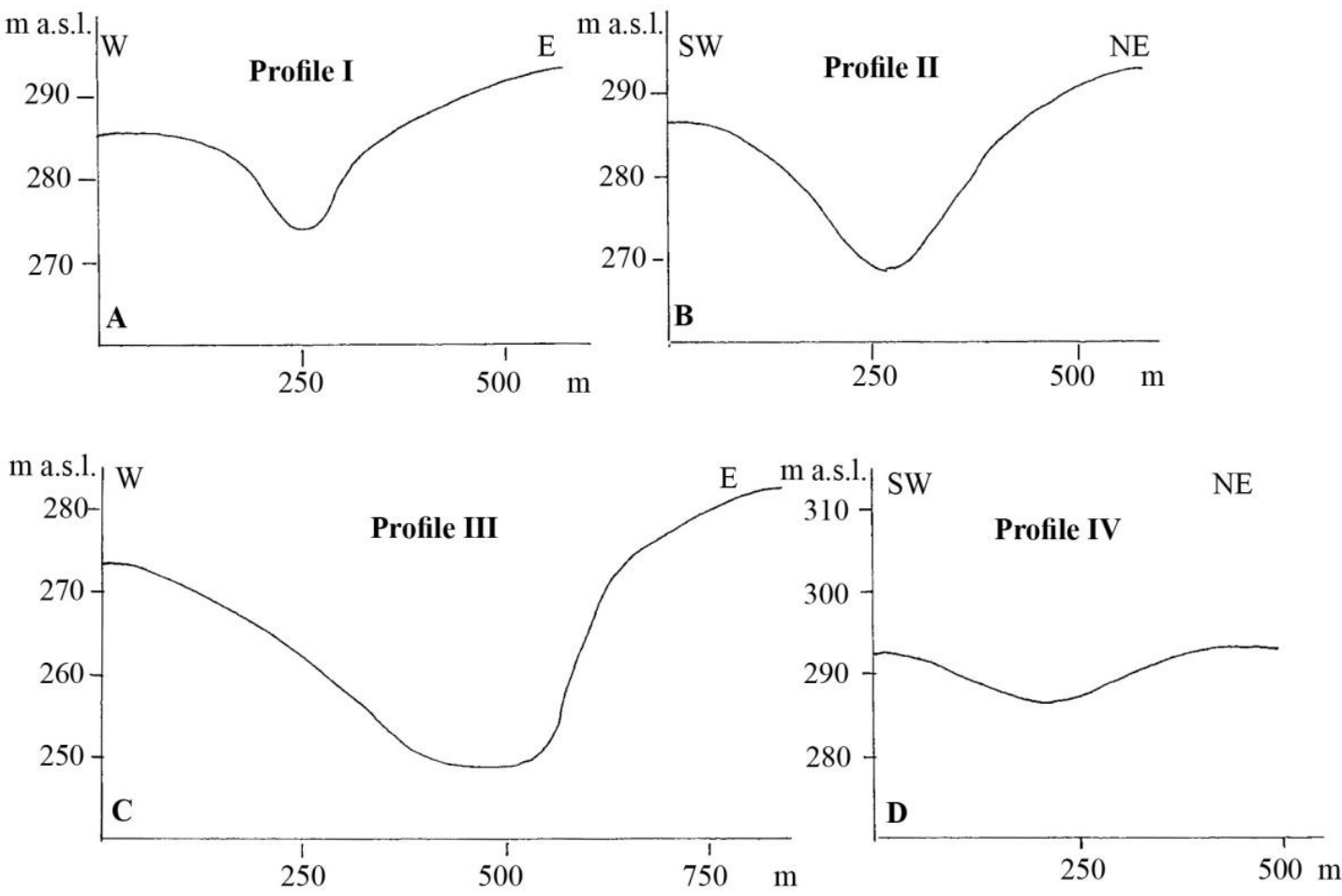

Fig. 1. Examples of transverse profiles through the Szotkówka and Pszczynka valleys

In the case of the valleys in the Kłokocinka catchment area the indices of ventilation vary depending on their shape and direction of their course. The values of the $D e_{w}$ index range from 51.6 to 68.8 (Tab. 3). The highest values for $D e_{w}$ were obtained for the upper part of the valley crossing the plateau to the north side and for its widest section, near the border of the study area, also of S-N course (Fig. 2). In these areas the degree of effective ventilation was described as sufficient, whereas in the other places a weak degree of ventilation was noted (Tab. 1, 3).
It can be reasoned from the obtained results that the valleys in the southern and western part of the study area running in N-S and NW-SE directions of the valley's axis, drained (sloped) in the southern and north-eastern direction are aired to a weak extent at the most, whereas the valleys in the northern part with S-N course and drained (sloped) in a northern direction - to a sufficient degree. This is important for the villages located in these areas - the northern and northeastern part of the test area is generally characterised by a better air quality. 

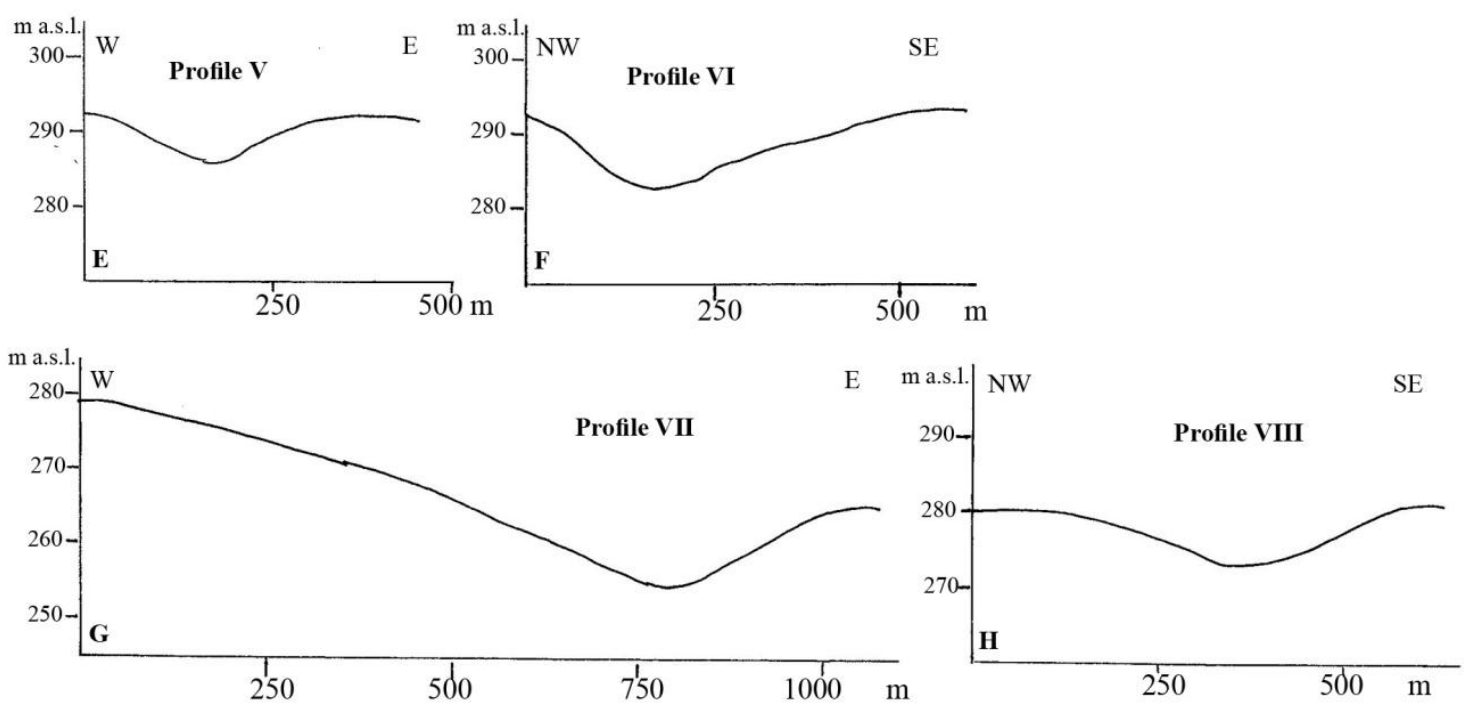

Fig. 2. Examples of transverse profiles through the valleys in the Kłokocinka catchment

Table 3. Index of ventilation $D$ and weighted mean value of the index of effective ventilation $D e_{w}$ for selected transverse profiles through the Kłokocinka valley

\begin{tabular}{|c|c|c|c|}
\hline Profile number & Directions & Index of ventilation $D$ & $\begin{array}{c}\text { Index of effective ventilation De } \\
\text { (weighted mean value) }\end{array}$ \\
\hline V & W $-\mathrm{E}$ & 46.2 & 66.2 \\
\hline VI & NW - SE & 36.0 & 51.6 \\
\hline VII & W $-\mathrm{E}$ & 48.0 & 68.8 \\
\hline VIII & NW $-\mathrm{SE}$ & 45.0 & 64.9 \\
\hline
\end{tabular}

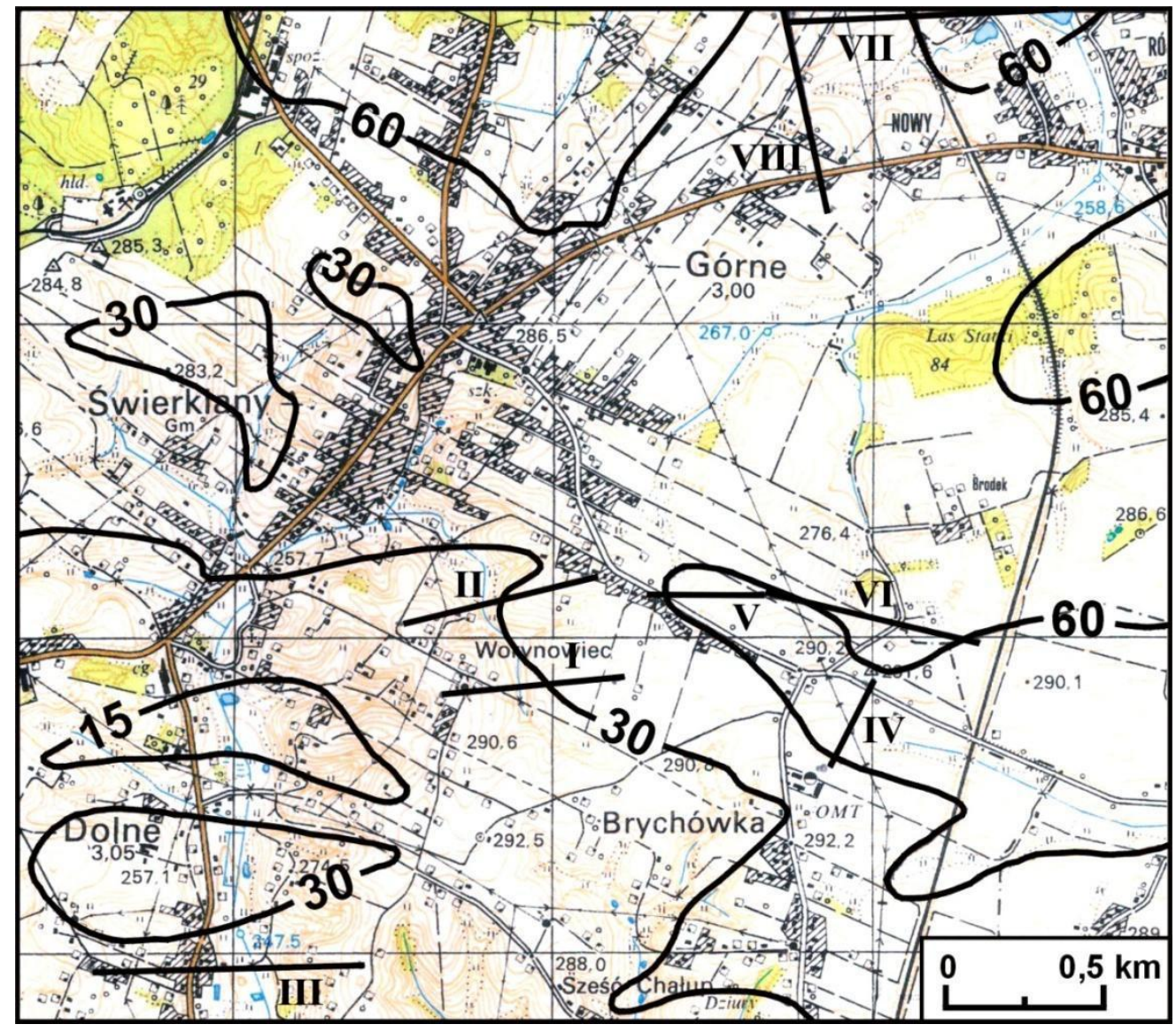

Fig. 3. The spatial distribution of the average value of the index of effective ventilation $D e_{w}$ in the vicinity of Jastrzębie Zdrój; I - profiles, 60 - values of the $\mathrm{De}_{\mathrm{w}}$ 
The spatial distribution of the average value of the index of effective ventilation $\left(D e_{w}\right)$ is shown in Fig. 3. The area was divided into four basic surfaces characterised by different degrees of effective ventilation, demarcated by isolines with values of $D e_{w}: 15,30$ and 60 . The south-western part, among others, within the meridian course of the valley of the River Szotkówka (N-S) and to the north of the spoil tip located near Dziury and Sześć Chałup hamlet, is characterised by the worst airing conditions. The degree of ventilation is very low there, and in some places - even extremely weak (Fig. 3). In the environs of Świerklany Dolne and Świerklany Górne the airing is weak, while the eastern and northern parts of the analysed area are sufficiently aired.

\section{Discussion}

The study on the ventilation of the valleys of the Silesian Upland are limited in number, which makes the discussion about the results difficult. A comparison of the degree of ventilation of the valleys in the study area with other areas shows both similarities and differences. For instance, Zielona Dolina situated in the area of the heavily polluted city of Sosnowiec (Dańdówka Plateau in the eastern part of the Silesian Upland) is sufficiently aired (RADOSZ, 2008). The Będkowska and Kluczwody Valleys in the Olkusz Upland, in the region of the Ojców National Park are aired to a weak degree and even to a very week degree (PichowsKA, 2009; SŁowIK, 2009). The Kudowa Zdrój health resort located at the outlet of the Kłodzko Valley has values for the indices of ventilation that are closest to that of the study area. The main valley there is aired to a very low degree, while the remaining valleys are aired to a weak and sufficient degree (BŁAŻEJCZYK, 1975). The values obtained for the Działy Grabowieckie valleys in the Lublin Upland can be held up as an example of different values for the indices of ventilation; the major part thereof is aired to a high and relatively high degree (RADOSZ, 2009). Therefore, the results of this studies indicate that the applied method can be an effective way of quantitatively determining the degree of airing of valleys. The combination of morphological characteristics of valleys and the characteristics of winds within one formula facilitates the easy determination of the intensity of the air flow. Spatial distributions of the ventilation index of the valleys can thus be used for the purpose of an assessment of the conditions of the local environment in land use planning. The example presented in this study shows that the index of effective ventilation, even if it is calculated for a relatively small area, reflects extremely well the characteristics of the local environment which are relevant from the perspective of the movement of contaminated air.

\section{Conclusion}

The conducted analysis allowed the definition of the degree of ventilation of the valleys within the environs of Jastrzębie Zdrój in the Rybnik Plateau and showed its variation depending on the local topographical conditions. The lowest values of the index of ventilation $(D)$ and effective ventilation $\left(D e_{w}\right)$ were recorded in almost all the main loessial valleys in the southern part of the area. This indicates their weak, or even extremely weak, degree of ventilation. The weakest level of airing was observed in the valley partitioned with the mining waste disposal site - this situation is favourable to greater sedimentation of solid pollutants. Taking into account the position of the location of the valley in the analysed area in relation to the Moravian Gate and the dominant direction of inflow of air masses, it can be assumed that stagnation of pollutants originating from the Czech works will be a frequent phenomenon where the degree of ventilation of these valleys is low. The valleys in the remaining area, open predominantly to $\mathrm{N}$ and $\mathrm{E}$, are most commonly aired to a sufficient degree. This is determined by their morphology, especially smaller depth, smaller denivelations and higher mean wind speed.

The applied method of assessment of the degree of ventilation of valleys is an effective method. The known morphometric data in the cross-sections and the wind rose illustrating the direction and the velocity of the wind enables a relatively precise determination of the anemological conditions at each point of the valley, which forms a basis for reasoning by analogy about the ventilation indices in neighbouring areas.

\section{References}

Bac S., Koźmiński C., Rojek M. 1993. Agrometeorologia. PWN, Warszawa.

Bar S., Orgill M.M. 1989. Influence of external meteorology on nocturnal valley drainage winds. J. Appl. Meteor., 28: 497-517.

Bąkowski R. 2000. Mountain and valley system and "Liptów winds". Prace Geogr., IG, UJ, 105: 183-191.

Błażejczyk K. 1975. Wyznaczanie stopnia przewietrzania dolin. Przegl. Geogr., 47, 1: 153-161.

Błażejczyk K., Kuchcik M. 2003. Klimat i bioklimat Głuchołaz $i$ Jarnołtówka. IGiPZ PAN, Warszawa. 
Bradley E.F. 1980. An experimental study of the profiles of wind speed, shearing stress and turbulence at the crest of a large hill. Quart. J. R. Meteorol. Soc., 106: 101-123.

Britter R.E., Hunt J.C.R., Richards K.J. 1981. Airflow over a two-dimensional hill: studies of velocity speed-up, roughness effects and turbulence. Quart. J. R. Meteorol. Soc., 107: 91-110.

Burzyńska A. 2009. Ocena przewietrzania dolin na Wyżynie Lubelskiej. WNoZ Uniw. Śląski, Sosnowiec (manuscript).

Charakterystyka klimatologiczna województwa katowickiego 1961-1990. IMGW Katowice, 1992.

Degórska V., Kamiński A., Radosz J. 1995. Ocena wpływu zwałowisk odpadów powęglowych na warunki meteorologiczne terenów przyległych w okolicy Jastrzębia. [in:] Przeobrażenia środowiska geograficznego $w$ przygranicznej strefie górnośląsko-ostrawskiego regionu przemysłowego, Mat. symp. polsko-czeskiego. WNoZ Uniw. Śląski, Park Krajobr. CKKRW, Sosnowiec: 15-22.

Doyle I.D., Shapiro M.A. 1999. Flow response to large-scale topography: the Greenland tip jet. Tellus, 51A: 728-748.

Dulias R. 2011. Impact of mining subsidence on the relief of the Rybnik Plateau, Poland. Zeit. für Geomorphologie, 55, 1: 25-36.

Dwucet K. 1981. Geomorfologiczna charakterystyka południowej części Płaskowyżu Rybnickiego. Geogr. Stud. et Dissert., 5: 7-28.

Dwucet K. 1986. Zróżnicowanie rzeźby na tle litologii utworów pyłowych Płaskowyżu Rybnickiego. Uniw. Śląski, Katowice.

Egger J. 1987. Valley winds and the diurnal circulation over plateaus. Mon. Wea. Rev., 115: 2177-2186.

Fleming G. 1983. Klimat - środowisko - człowiek. Państ. Wyd. Rol. i Leśne, Warszawa.

Hess M. 1969. Klimat podregionu miasta Krakowa. Folia Geogr., Ser. Geogr.-phys., 3: 5-65.

Jankowski A.T. 1986. Antropogeniczne zmiany stosunków wodnych na obszarze uprzemysłowionym i zurbanizowanym (na przykładzie Rybnickiego Okręgu Węglowego). Wyd. Uniw. Śląskiego, Katowice.

Kamiński A., Radosz J. 1991. Zmiany zróżnicowania topoklimatów okolic Jastrzębia Zdroju w Rybnickim Okręgu Weglowym. [in:] Człowiek i jego środowisko w Górnośląsko-Ostrawskim rejonie przemysłowym. Mat. symp. polsko-czeskiego, Sosnowiec: 55-61.

Kaps E. 1955. Zur Frage der Durchlüftung von Tälern im Mittelgebirge. Met. Rundschau, B, 8, H, 3/4.

Klein J. 1967. Charakterystyka fitoklimatu badanych powierzchni na tle warunków mezoklimatycznych Ojcowa. Stud. Naturae, Ser. A., 1: 25-47.

Kłysik K. 1985. Wpływ struktury termiczno-wilgotnościowej przyziemnych warstw powietrza na klimat lokalny $w$ wybranych warunkach terenowych. Acta Geogr. Lodz., 49. ŁTW, Ossolineum.

Kondracki J. 1998. Geografia regionalna Polski. PWN Warszawa.

Krawczyk B., Błażejczyk K. 1982. Kształtowanie się odczuwalnych warunków termicznych w terenach górskich. Przegl. Geogr., 54, 1-2: 81-86.

Mapa geologiczna Polski 1:200 000, ark. Cieszyn, Gliwice, IG, Warszawa, 1979.

Mapa topograficzna 1:10 000 ark. Świerklany Górne. PPGK, 1993.

Mikita T., Klimánek M. 2010. Topographic exposure and its practical applications. J. of Landscape Ecol., 3, 1: 42-51.

Młynarczyk M. 2002. Warunki klimatyczne i zanieczyszczenie powietrza na terenie miasta Jastrzębia Zdroju. WNoZ Uniw. Śląski, Sosnowiec (manuscript).
Ngo T., Letchfors Ch. 2008. A comparison of topographic effects on gust wind Speer. J. of Wind Engineering and Industrial Aerodynamics, 96, 12: 2273-2293.

Parczewski W. 1960. Klasyfikacja przedziałów prędkości wiatrów w zastosowaniu do opracowań klimatycznych i bioklimatycznych. Przegl. Geofiz. T V(XIII), 2: 117-122.

Petersen G.N., Kristjánsson J.E., Ólafsson H. 2005. The effect of upstream wind direction on atmospheric flow in the vicinity of a large mountain. Quart. J. R. Meteorol. Soc., 131: 1113-1128.

Pichowska J. 2009. Przewietrzalność dolin w PK Dolinki Krakowskie na przykładzie Doliny Kluczwody. WNoZ Uniw. Śląski, Sosnowiec (manuscript).

Radomski Cz. 1977. Agrometeorologia. PWN, Warszawa.

Radosz J. 2007a. Przewietrzanie dolin w okolicy Jastrzębia Zdroju (Płaskowyż Rybnicki). Kształt. środ. geogr. i ochr. przyr. na obsz. uprzem. i zurban., 38: 23-32.

Radosz J. 2007b. Zróżnicowanie Płaskowyżu Rybnickiego w oparciu o wskaźnik przewietrzania. [in:] Strzyż M., Świerszcz A. (eds.) Badania regionalne - wybrane problemy. Nauki geograficzne $w$ badaniach regionalnych, 3. AŚ, PTG, Kielce: 493-501.

Radosz J. 2007c. Topoklimat Płaskowyżu Rybnickiego w świetle niektórych elementów bilansu cieplnego. Acta Geogr. Silesiana, 1: 45-51.

Radosz J. 2008. Zróżnicowanie topoklimatyczne miasta Sosnowca. [in:] Jankowski A.T. (ed.) Oblicza miasta. Rocz. Sosnowiecki, 14, Muzeum w Sosnowcu: 1-39.

Radosz J. 2009. Wpływ morfologii dolin Działów Grabowieckich na wielkość ich przewietrzania. Acta Geogr. Silesiana, 6: 61-68.

Radosz J., Caputa Z., Kamiński A. 2004. Changes of Jastrzębie Zdrój topoclimate during periods of economic transformation. [in:] Geographical Information Systems in Research \& Practice, Zagreb, Croatia: 149-156.

Rampanelli G., Zardi D., Rotunno R. 2004. Mechanism of upvalley winds. J. Atmos. Sci., 61: 3097-3111.

Reuder J., Egger J. 2006. Diurnal circulation on the South American Altiplano: observations in a valley and at a pass. Tellus, Ser. A, 58: 254-262.

Słowik M. 2009. Przewietrzanie dolin na Wyżynie KrakowskoCzęstochowskiej na przykładzie Doliny Będkowskiej. WNoZ Uniw. Śląski, Sosnowiec (manuscript).

Smith R.B. 1978. The influence of mountains on the atmosphere. Adv. in Geophysics, 21: 87-230.

Świętoń J. 1981. Mezoklimat Rybnickiego Okręgu Węglowego. WNoZ Uniw. Śląski, Sosnowiec (manuscript).

Taylor P.A., Lee R.J. 1984. Simple guidelines for estimating wind speed variations due to small scale topographic features. Climat. Bull., 18, 2: 3-32.

Trepińska J., Kowanetz L. 2000. Dependence of wind and speed on the orography in the western part of Beskidy Mountains. Prace Geogr., IG, UJ, 105: 164-180.

Ukleja E. 2009. Przewietrzanie dolin na Wyżynie Lubelskiej. WNoZ Uniw. Śląski, Sosnowiec (manuscript).

Whiteman C.D., Doran J.C. 1993. The relationship between overlying synoptic-scale flows and winds within a valley. J. Appl. Meteor., 32: 1669-1682.

Zardi D., Whiteman C.D. 2012. Diurnal mountain wind systems. [in:] Chow F.K., De Wekker S.F.J., Snyder B.J. (eds.) Mountain weather research and forecasting. Springer, Berlin: 1-74. 